\title{
IZVANREDNI PRAVNI LIJEKOVI U UPRAVNOM SPORU
}

\author{
Meri Dominis Herman, dipl. iur.*
}

\author{
UDK 347.958 \\ https://doi.org/10.30925/zpfsr.42.2.16 \\ Ur.: 4. ožujka 2021. \\ Pr.: 19. lipnja 2021. \\ Stručni rad
}

\begin{abstract}
Sažetak
U ovom se radu analiziraju dva izvanredna pravna lijeka propisana Zakonom o upravnim sporovima; obnova upravnog spora $i$ zahtjev za izvanredno preispitivanje zakonitosti pravomoćne presude. Iznose se njihove specifičnosti i razrađuju posebnosti s prikazom prakse prvostupanjskih upravnih sudova, Visokog upravnog suda Republike Hrvatske i Vrhovnog suda Republike Hrvatske. Autorica zaključuje da postoji propust zakonodavca kada se opredijelio samo za obnovu spora okončanog presudom, a ne i rješenjem, što se može ispraviti $u$ nekim daljnjim noveliranjima Zakona o upravnim sporovima. Također, upozorava na nejasnoće pri reguliranju rokova za obnovu upravnog spora $i$ uočava kako je veliki broj podnesenih prijedloga za obnovu spora odmah odbačen, a vrlo je mali broj pozitivnih odluka o prijedlogu. Autorica zaključuje da to ukazuje na činjenicu da su odluke upravnih sudova pravno i procesno utemeljene ili da se stranke zbog složene procesne koncepcije rijetko upuštaju u ponovni upravni spor. Nadalje, autorica se odlučuje za pristup zakonodavca pri reguliranju zahtjeva za izvanredno preispitivanje zakonitosti pravomoćne presude. Omogućavanjem strankama da podnose zahtjeve izravno Vrhovnom sudu Republike Hrvatske znatno bi se opteretio taj sud i stavilo bi ga se u ulogu suda trećega stupnja što nije bila namjera zakonodavca pri propisivanju toga izvanrednog pravnog lijeka.
\end{abstract}

Ključne riječi: izvanredni pravni lijekovi; obnova upravnog spora; zahtjev za izvanredno preispitivanje zakonitosti pravomoćne odluke; Zakon o upravnim sporovima.

\section{1. $U V O D$}

Zakonom o upravnim sporovima (dalje: ZUS) ${ }^{1}$ propisan je postupak kojim upravni sudovi odlučuju o zakonitosti odluka javnopravnih tijela o pravima, obvezama i pravnim interesima fizičkih i pravnih osoba i drugih stranaka te o zakonitosti

* Meri Dominis Herman, dipl. iur., sutkinja Upravnog suda u Zagrebu; meri.dominisherman@ uszg.pravosudje.hr. ORCID: https://orcid.org/ 0000-0002-6875-6088.

1 Zakon o upravnim sporovima, Narodne novine, br. 20/10., 143/12., 152/14., 94/16., 29/17. 
postupanja javnopravnih tijela iz područja upravnog prava. ${ }^{2}$ ZUS koji je na snazi, donesen je 12. veljače 2010., a u dosadašnjoj primjeni pokazalo se da ima brojne nedostatke, nedorečenosti pa i ograničenja zbog čega je tri puta noveliran. ${ }^{3}$

Sudska odluka u upravnom sporu nakon što postane pravomoćna (bez obzira na to je li do pravomoćnosti došlo nakon korištenja redovitog pravnog lijeka ili neovisno o njemu) ne može se više pobijati redovitim pravnim lijekom; žalbom. Međutim, u nekim slučajevima nužno je osigurati pravnu zaštitu i protiv pravomoćnih sudskih odluka, pa su u upravnom sudskom postupku kao izvanredni pravni lijekovi propisani obnova spora, ${ }^{4}$ koja nije novi pravni lijek jer je postojala i u ranijem ZUS-u ${ }^{5}$ i zahtjev za izvanredno preispitivanje zakonitosti pravomoćne presude, ${ }^{6}$ koji je kao pravno sredstvo uveden u hrvatsko upravno sudovanje ZUS-om iz 2010. Naime, stari ZUS kao izvanredne pravne lijekove propisivao je obnovu spora i zahtjev za zaštitu zakonitosti.

ZUS-om iz 2010., u trećem dijelu Zakona propisani su pravni lijekovi obnova spora u Glavi II. i zahtjev za izvanredno preispitivanje zakonitosti pravomoćne presude u Glavi III. Navedena su dva instituta nakon stupanja na snagu ZUS-a doživjela izmjene, obnova spora Novelom ZUS-a iz 2014. te zahtjev za izvanredno preispitivanje zakonitosti pravomoćne presude Novelom ZUS-a iz 2012. i 2014.

Razlozi za obnovu spora propisani su odredbom čl. 76. st. 1. ZUS-a. Prema toj odredbi spor okončan presudom obnovit će se na prijedlog stranke:

1. ako je konačnom presudom Europskog suda za ljudska prava odlučeno o povredi temeljnoga ljudskog prava ili slobode na drukčiji način od presude suda,

2. ako se presuda temelji na prethodnom pitanju, a nadležni sud ili drugo javnopravno tijelo o tom je pitanju poslije odlučilo u bitnim točkama drukčije,

3. ako je do odluke suda došlo zbog kaznenog djela suca ili službenika suda,

4. ako se odluka suda temelji na ispravi koja je krivotvorena, ili u kojoj je ovjeren neistinit sadržaj, ili ako se odluka suda temelji na lažnom iskazu svjedoka, vještaka ili stranke,

5. ako je u donošenju odluke sudjelovao sudac koji je prema čl. 15. ovoga Zakona morao biti izuzet,

6. ako stranka sazna za nove činjenice, te nađe ili stekne mogućnost da upotrijebi nove dokaze na temelju kojih bi spor bio povoljnije riješen za nju da su te činjenice ili dokazi bili izneseni ili upotrijebljeni u prijašnjem sudskom postupku te

7. ako zainteresiranoj osobi nije bila dana mogućnost sudjelovanja u upravnom sporu.

2 Čl. 1. ZUS-a.

3 Zakon o izmjenama i dopunama ZUS-a iz 2012., Narodne novine, br. 143/12. (dalje: Novela ZUS-a 2012.), Zakon o izmjenama i dopunama ZUS-a iz 2014., Narodne novine, br. 152/14. (dalje: Novela ZUS-a 2014.) i Zakon o izmjenama i dopunama ZUS-a iz 2017., Narodne novine, br. 29/17. (dalje: Novela ZUS-a 2017.).

4 Čl. 77. i 78. ZUS-a.

5 Zakon o upravnim sporovima, Narodne novine, br. 53/91., 9/92. i 77/92. (dalje: stari ZUS).

6 Čl. 78. ZUS-a. 
Zahtjev za izvanredno preispitivanje zakonitosti pravomoćne presude uveden je u hrvatski pravni sustav 2010. i riječ je o izvanrednom pravnom lijeku koji se može, za razliku od obnove upravnog spora, podnijeti i protiv presude i protiv rješenja. Podnošenje navedenoga izvanrednog pravnog lijeka ovisi isključivo o diskreciji Državnog odvjetništva Republike Hrvatske (dalje: DORH), ili o postojanju ili nepostojanju razloga za njegovo podnošenje Vrhovnom sudu Republike Hrvatske (dalje: Vrhovni sud).

Odredbom čl. 78. ZUS-a propisani su uvjeti za podnošenje zahtjeva i odlučivanje o zahtjevu. Prema toj odredbi, stranke u upravnom sporu mogu zbog povrede zakona predložiti DORH-u podnošenje zahtjeva za izvanredno preispitivanje zakonitosti pravomoćne presude i rješenja upravnog suda ili Visokog upravnog suda Republike Hrvatske (dalje: Visoki upravni sud) (st. 1.). Zahtjev za izvanredno preispitivanje zakonitosti pravomoćne presude može podnijeti DORH u roku od šest mjeseci od dana dostave pravomoćne sudske presude strankama. DORH ovaj zahtjev može podnijeti i po službenoj dužnosti (st. 2.). O zahtjevu odlučuje Vrhovni sud, u vijeću koje čini pet sudaca (st. 3.). Nepravodoban zahtjev ili zahtjev koji je podnijela neovlaštena osoba, sud će odbaciti rješenjem (st. 4.). Ako nadležni sud ne odbaci zahtjev, dostavit će ga protivnoj stranci koja može u roku od 30 dana podnijeti odgovor na zahtjev (st. 5.). Vrhovni sud rješava zahtjev na nejavnoj sjednici, a pobijanu odluku ispituje samo u granicama zahtjeva (st. 6.). Sud protiv čije je presude podnesen zahtjev iz st. 2. ovoga članka i javnopravno tijelo kao tuženik obvezni su bez odlaganja dostaviti Vrhovnom sudu, na njegov zahtjev, sve spise predmeta (st. 7.). Ako Vrhovni sud usvoji zahtjev, može ukinuti presudu i vratiti predmet na ponovno rješavanje ili preinačiti presudu (st. 8.).

\section{OBNOVA SPORA}

Obnova spora jedan je od izvanrednih pravnih lijekova normiran ZUS-om koji omogućuje osporavanje pravomoćnih upravnih presuda u cilju njihova stavljanja izvan snage, te ponavljanje ranije okončanog upravnog spora u kojem su one donesene zbog određenih zakonom normiranih razloga. Osim što je izvanredni pravni lijek jer se njime omogućava osporavanje pravomoćnih presuda, po svojoj je naravi i remonstrativni pravni lijek jer o njemu odlučuje sud koji je donio odluku protiv koje se podnosi; upravni sud ili Visoki upravni sud. Obnova spora je nesuspenzivan pravni lijek jer ne odgađa izvršenje presude, ali i samostalan pravni lijek, jer se o njemu odlučuje neovisno o drugim pravnim lijekovima. Riječ je o pravnom lijeku za čiju dopustivost moraju biti ispunjene naprijed navedene zakonske pretpostavke. Posebnost obnove spora ogleda se u tome što se sudski spor okončan presudom može obnoviti, ali ne i upravni spor okončan rješenjem ${ }^{7}$ te su ograničeni i razlozi zbog kojih se obnova može predložiti.

7 Visoki upravni sud Republike Hrvatske, Usž-100/20-2 od 13. svibnja 2020. u kojoj sud ističe: ...uvidom u prijedlog i ovosudni spis Usž-1005/18 kao i u odluku Usž-4494/19., na kojoj tužitelj temelji svoj zahtjev, vidljivo je da se ne radi o presudama nego o rješenjima. Budući da se obnoviti može sudski spor okončan presudom, a ne okončan rješenjem to nisu ispunjene pretpostavke iz članka 76. stavak 1. ZUS-a. 


\subsection{Razlozi za obnovu spora}

Razlozi za obnovu spora obuhvaćeni su u odredbi čl. 76. st. 1. ZUS-a, i alternativno su i strogo normirani. To znači da nema mogućnosti na pozivanje nekoga drugog razloga izvan ondje navedenih, a suprotno bi rezultiralo nedopuštenošću prijedloga i posljedično tome njegovog odbacivanja. ${ }^{8} \mathrm{U}$ nastavku radu razlozi će biti prikazani pojedinačno.

\subsubsection{Ako je konačnom presudom Europskog suda za ljudska prava odlučeno o povredi temeljnoga ljudskog prava ili slobode na drukčiji način od presude suda}

Sve države koje su potpisnice (Europske) Konvencije za zaštitu ljudskih prava i temeljnih sloboda te dodatnih protokola uz tu Konvenciju moraju poštovati prava i slobode zajamčene Konvencijom i ona je sastavni dio hrvatskoga pravnog poretka od 6. studenoga 1997., te su je sva tijela državne vlasti obvezna primjenjivati u svom postupanju, a što se u praksi najčešće odnosi na pravosudna tijela. Europski sud za ljudska prava (dalje: ESLJP) pruža supsidijarnu zaštitu ako su nacionalna tijela, ovdje sudovi, propustila primijeniti ili su krivo primijenila neku od odredbi Konvencije. To znači da djeluje kao zaštitnik od povreda koje nisu ispravljene na nacionalnoj razini. Nacionalni sudovi moraju voditi računa o sudskoj praksi ESLJP-a u vođenju postupka i donošenju odluka jer su sve presude i odluke obvezujuće za državu. Sudovi također moraju poduzeti sve da se one ne ponavljaju, čime pokazuju da prihvaćaju presude ESLJP-a i primjenjuju standarde u smislu zaštitite ljudskih prava. Poznavanje, ali posebno razumijevanje, sudske prakse pokazuje se kao nužan preduvjet za pravilnu primjenu same Konvencije i ujedno otklanjanje mogućnosti da stranke pribjegavaju podnošenju prijedloga za obnovu upravnog spora iz razloga propisanog odredbom čl. 76. st. 1. t. 1. ZUS-a, a kada se konačnom presudom ESLJP-a o povredi temeljnih ljudskih prava odluči na drukčiji način od presude suda.

U situaciji kada ESLJP utvrdi povredu ljudskog prava ili temeljne slobode zajamčene Konvencijom, stranka može u roku od 30 dana, od dana kada je saznala za razlog obnove (od konačnosti odluke ESLJP-a), podnijeti zahtjev sudu (upravnom sudu ili Visokom upravnom sudu) koji je donio pravomoćnu presudu kojom je povrijeđeno neko ljudsko pravo ili temeljna sloboda za stavljanje takve presude izvan snage. Konačnost presude ESLJP-a nastupa različito, ovisno o tome koliko je sudaca sudjelovalo u donošenju presude. U predmetima u kojima je utvrđeno da je došlo do povrede nekoga ljudskog prava ili temeljne slobode u upravnom sporu, zastupnica Vlade u pravilu obavještava sud koji je sudio u pravnom stupnju o donesenoj presudi i o datumu njezine konačnosti te dostavlja sudu prijevod presude na hrvatskom jeziku. Ako sudu pred kojim je podnesen zahtjev u konkretnom slučaju za obnovu spora nije dostavljena obavijest o konačnosti presude i prijevod presude, sud može od zastupnice Vlade zatražiti obavijest o postojanju, sadržaju i datumu konačnosti

8 Čl. 77. st. 1. ZUS-a.

9 Konvencija za zaštitu ljudskih prava i temeljnih sloboda, Narodne novine, Međunarodni ugovori, br. 18/97., 6/99., 14/02., 13/03., 9/05., 1/06., 2/10. (dalje: Konvencija). 
presude Europskog suda. ${ }^{10}$

U prijedlogu za obnovu spora zbog navedenog razloga, sud ne ulazi u ocjenu pravilnosti odluke ESLJP-a, već je obvezan provesti postupak i poštovati stajalište izneseno u presudi ESLJP-a. Pretpostavke za dopustivost obnove zbog ovoga razloga bile bi:

Pravomoćna presuda upravnog suda ili Visokog upravnog suda u kojoj je došlo do povrede neke od odredbi Konvencije, konačna odluka ESLJP-a kojom je utvrđena povreda Konvencije.

Prijedlog za obnovu spora podnesen sudu koji je donio pravomoćnu presudu u zakonskom roku od 30 dana od dana konačnosti odluke ESLJP-a.

Upravni sud u Zagrebu je, primjerice, u odluci UsI-4965/13-5 od 26. ožujka 2015. odbacio prijedlog za obnovu upravnog spora okončanog presudom toga suda u čijem je prijedlogu podnositelj naveo kako smatra da postoji osnova za obnovu spora na temelju konačne presude ESLJP u predmetu Damjanović - Maktouf protiv Bosne i Hercegovine (broj: 2312/08 i 24179/08), kojom je odlučeno da je protupravna retroaktivna primjena propisa. Sud je naveo: Podnositelj prijedloga nije učinio vjerojatnim postojanje zakonske osnove za obnovu spora. Naime, razlog obnove pravomoćno okončanog upravnog spora, u skladu s odredbom čl. 76. st. 1.t. 1. ZUS-a, konačna je presuda Europskog suda za ljudska prava u kojoj je utvrđena povreda ljudskih prava i temeljnih sloboda u slučaju koji je bio predmet upravnog spora čija se obnova predlaže. Imajući $u$ vidu, da je obnova spora izvanredni pravni lijek kojim se omogućuje stavljanje izvan snage pravomoćne sudske odluke, ispitivanje osnovanosti prijedloga za obnovu spora mora biti utemeljeno na povredama ljudskih prava $i$ temeljnih sloboda povrijeđenih tom odlukom, a koje povrede su utvrđene presudom Europskog suda za ljudska prava u konkretnom predmetu. Kako se podnositelj prijedloga poziva na presude Europskog suda za ljudska prava, koje se ne odnose na predmet upravnog spora čija se obnova predlaže, sud je, na temelju čl. 77. st. 1. ZUS-a, odlučio kao u izreci.

Međutim tu treba imati na umu i činjenicu da je Ustavni sud Republike Hrvatske (dalje: Ustavni sud) u odluci U-III-3304/2011 od 23. siječnja 2013. ponovio opća ustavnopravna stajališta o obvezama sudova pri izvršenju presuda ESLJP-a. Naime, Ustavni sud je u spomenutoj odluci naveo slijedeće: Zaključno, u pitanjima izvršenja presuda Europskog suda domaća sudska praksa mora se izgrađivati tako da uvažava međunarodnopravne obveze koje za Republiku Hrvatsku proizlaze iz Konvencije. Mora biti u suglasnosti s navedenim relevantnim pravnim stajalištima i praksom Europskog suda jer su one za Republiku Hrvatsku obvezujući međunarodnopravni standardi. To znači da je svaka presuda protiv Republike Hrvatske u kojoj je Europski sud utvrdio povredu Konvencije za nadležna domaća tijela - nova činjenica. Snagu te nove činjenice najbolje je opisao njemački Savezni ustavni sud kad je u povodu presude Europskog suda M. protiv Njemačke (17. prosinca 2009., zahtjev br. 19359/04) te više istovrsnih presuda koje su poslije toga uslijedile u svojoj presudi Sigurnosni zatvor

10 Damir Kontrec i Vitomir Boić, Konvencija za zaštitu ljudskih prava i temeljnih sloboda i praksa ESLJP - Građanskopravni aspekt, Priručnik za voditelje/ice (Zagreb: Pravosudna akademija, 2017.), 22. 
I. od 4. svibnja 2011. utvrdio: "1. Odluke Europskog suda, koje sadrže nove aspekte za tumačenje Temeljnog zakona, ekvivalentne su pravno relevantnim promjenama koje mogu dovesti do prevladavanja učinaka konačnih i obvezujućih odluka i samog Saveznog ustavnog suda." ("1. Entscheidungen des Europäischen Gerichtshofs für Menschenrechte, die neue Aspekte für die Auslegung des Grundgesetzes enthalten, stehen rechtserheblichen Änderungen gleich, die zu einer Überwindung der Rechtskraft einer Entscheidung des Bundesverfassungsgerichts führen können." BVerfG, Urteil des Zweiten Senats vom 4. Mai 2011 - 2 BvR 2365/09-2 BvR 740/10-2 BvR 2333/08-2 BvR 1152/10-2 BvR 571/10, Absatz-Nr., 1-178). Ustavni sud na kraju podsjeća i na čl. 31. st. 3. Ustava koji izrijekom dopušta mogućnost obnove kaznenog postupka ako je to propisano zakonom , u skladu s međunarodnim ugovorom”. To zaključno znači da je presuda Europskog suda uvijek ,nova činjenica” koja mora dovesti do ispitivanja osnovanosti zahtjeva za izmjenu pravomoćne sudske odluke na temelju odluke Europskog suda, ako takav zahtjev bude podnesen.

\subsubsection{Ako se presuda temelji na prethodnom pitanju, a nadležni sud ili drugo javnopravno tijelo o tom je pitanju poslije odlučilo u bitnim točkama drukčije}

Odredbom čl. 76. st. 1. t. 2. ZUS-a, kao razlog obnove spora predviđena je i situacija kada se presuda temelji na prethodnom pitanju, ${ }^{11}$ a nadležni sud ili drugo javnopravno tijelo o tom je pitanju poslije odlučilo u bitnim točkama drukčije. To bi bila riječ o situaciji kada upravni sud ili Visoki upravni sud u upravnom sporu odluči sam riješiti prethodno pitanje koje se pojavi pred njim, a da prekine upravni spor $^{12} \mathrm{i}$ ne pričeka odluku tijela nadležnog za rješavanje tog pitanja. Tu je bitno naglasiti da je obnova spora moguća samo onda kada se takvo pitanje riješi drukčije, a ne u situaciji kada god nadležno tijelo riješi prethodno pitanje. Naime, za drukčije tumačenje nema mjesta jer suprotno ne bi niti postojao interes predlagatelja za obnovom spora koji bi rezultirao istom odlukom. Nadalje, iako odredba to ne govori, logično je da prethodno pitanje o kojem je odlučilo neko javnopravno tijelo ili sud mora biti riješeno pravomoćnom odlukom tog nadležnoga javnopravnog tijela i suda.

Kada stranke podnose zahtjev za obnovu spora zbog navedenoga razloga u sudskoj praksi upravnih sudova zabilježeno je da u većini slučajeva svoje prijedloge temelje na činjenici da se pravomoćna presuda upravnog suda koja je predmet obnove temelji na prethodnom pitanju o kojem je odlukama drugih sudova (npr. nadležnog županijskog suda, Visokog upravnog suda, Ustavnog suda i sl.) odlučeno drukčije.

Odlučujući o takvom prijedlogu, primjerice, Upravni sud u Osijeku je u odluci UsI-1540/13-11 od 30. svibnja 2016. naveo: ....presuda Visokog upravnog suda Republike Hrvatske, poslovni broj: Usž-1491/15-2 od 24. rujna 2015., kao i odluka Ustavnog suda Republike Hrvatske broj: U-III-6878/2014 od 5. ožujka 2015., nemaju značaj rješenja prethodnog pitanja u sporu koji se vodio kod ovoga Suda pod

11 Prethodno pitanje ili prejudicijalno pitanje odnosi se na pravno pitanje koje predstavlja samostalnu pravnu cjelinu bez čijeg se rješenja ne može riješiti glavna stvar. Vidi: Siniša Triva i Mihajlo Dika, Građansko parnično procesno pravo (Zagreb: Narodne novine, 2004.), 71.

12 Čl. 45. st. 2. ZUS-a. 
poslovnim brojem: UsI-446/14, obzirom da Sud u predmetnom upravnom sporu nije sam riješio niti jedno prethodno pitanje te svoju odluku utemeljio na takvom pitanju, niti je prekinuo upravni spor do donošenja odluke o prethodnom pitanju.

Upravni sud u Zagrebu je, primjerice, u odluci UsI-910/19-31 od 22. ožujka 2019. naveo: ...dakle, sud je citiranom presudom riješio spor na podlozi činjenica koje su utvrđene u upravnom postupku izvlaštenja te je ocijenio zakonitim način na koji je upravno tijelo riješilo prethodno pitanje, a nije sam rješavao prethodno pitanje. Upravo iz tog razloga tužiteljica je presudom upućena da može tražiti obnovu upravnog postupka temeljem Zakona o općem upravnom postupku, a ne obnovu upravnog spora temeljem Zakona o upravnim sporovima. Stoga prijedlog za obnovu nije dopušten.

\subsubsection{Ako je do odluke suda došlo zbog kaznenog djela suca ili službenika suda}

Iz sadržaja navedene zakonske odredbe proizlazi da sudac ili službenik suda moraju počiniti kazneno djelo propisano Kaznenim zakonom, ${ }^{13}$ a to bi značilo da odluka suca mora biti posljedica kaznenog djela bez kojeg do takve odluke, odnosno odluke takvog sadržaja ne bi niti došlo (uzročna veza). U obzir mogu doći različita kaznena djela, primjerice: zlouporaba položaja i ovlasti, ${ }^{14}$ krivotvorenje službene isprave, ${ }^{15}$ primanje mita ${ }^{16}$ i sl. ZUS-om nije izričito propisano kakve se dodatne pretpostavke moraju ispuniti da bi se stranka mogla pozvati u svom prijedlogu na ovaj razlog. Naime, može se zaključiti da je za obnovu spora iz ovog razloga potrebna pravomoćna osuđujuća presuda u kaznenom postupku. Međutim, ako je kazneni postupak obustavljen i ako se ne može provesti, postavlja se pitanje bi li sud u upravnom sporu o postojanju kaznenog djela morao odlučivati kao o prethodnom pitanju, kao primjerice u parničnom postupku u povodu ponavljanja postupka zbog istog razloga i takva bi odluka imala pravni učinak samo u postupku ponavljanja ${ }^{17}$ ili bi upravni sud prijedlog za obnovu spora odbacio zbog činjenice da stranka nije učinila vjerojatnim prijedlog za obnovu spora? U sudskoj praski upravnih sudova nije zabilježen niti jedan slučaj gdje bi bila dopuštena obnova upravnog spora zbog navedenoga razloga. Ako je prijedlog i podnesen, on je odbačen zbog toga što stranka nije učinila vjerojatnim postojanje zakonske osnove za obnovu spora.

2.1.4. Ako se odluka temelji na ispravi koja je krivotvorena ili u kojoj je ovjeren neistinit sadržaj ili ako se odluka temelji na lažnom iskazu svjedoka, vještaka ili stranke

Navedena je odredba sadržajno istovjetna prethodnom razlogu za obnovu spora. Kao što je i navedeno u prethodnom odlomku, mora postojati uzročna veza između

13 Kazneni zakon, Narodne novine, br. 125/11., 144/12., 56/15., 61/15., 101/17., 118/18., 126/19. (dalje: KZ).

14 Čl. 291. KZ.

15 Čl. 278. KZ.

16 Čl. 293. KZ.

17 Zorislav Kaleb, Djelovanje kaznene presude na parnični postupak (Zagreb: Vizura, 2008.), 124. 
krivotvorene isprave ili isprave u kojoj je ovjeren neistinit sadržaj, ${ }^{18}$ lažni iskaz ${ }^{19}$ i odluka, odnosno odluka mora biti utemeljena na krivotvorenoj ispravi ili ispravi u kojoj je ovjeren neistinit sadržaj ili sadržaj lažnog iskaza svjedoka, vještaka ili stranke. U takvoj, kao i u prethodno navedenoj situaciji se podrazumijeva postojanje pravomoćne presude kojom je utvrđeno počinjenje kaznenog djela krivotvorenja isprave, ovjere neistinitog sadržaja ili lažnog iskaza svjedoka, vještaka ili stranke, kao podloge za donošenje odluke suda. Nužno je navesti da nije lažna isprava svaka isprava u kojoj su navedeni netočni podatci o određenim činjenicama, već je lažna isprava ona koja je lažno nastala počinjenjem kaznenog djela, te ju je kao istinitu prihvatio sud u ranijem sporu i koja je utjecala na donošenje presude. ${ }^{20}$

\subsubsection{Ako je u donošenju odluke sudjelovao sudac koji je prema članku 15. ZUS-a morao biti izuzet}

Odredbom čl. 15. st. 1. ZUS-a navedeni su razlozi kada sudac ne može odlučivati niti sudjelovati u sporu. ${ }^{21}$

Prema navedenoj odredbi i sudac i stranka mogu tražiti izuzeće. ${ }^{22}$ Naime, stranka je obvezna podnijeti zahtjev za izuzeće suca čim sazna za razlog za izuzeće, a najkasnije do zaključenja rasprave, a ako nije bilo rasprave do donošenja odluke. ${ }^{23}$ Obnova spora iz ovoga razloga, iako to odredbom nije propisano, mogla bi se dopustiti samo u situaciji ako stranka bez svoje krivnje navedeni razlog nije mogla iznijeti u postupku prije donošenja pravomoćne odluke. U suprotnom ako je takav razlog stranka isticala bezuspješno u žalbi se ne bi mogla pozivati njega u obnovi spora. Naime, podnositelj prijedloga obvezan je dokazati da taj razlog bez svoje krivnje nije mogao isticati u prijašnjem postupku, što znači da je teret dokaza na stranci. Međutim, s obzirom na to da je s druge strane, obveza suca da prekine rad na predmetu čim sazna za razloge za njegovo izuzeće koji nisu i ne bi smjeli biti nepoznati sudu u prijašnjem postupku, utoliko bi se zahtijevanje nepostojanja krivnje na strani podnositelja prijedloga zbog neiznošenja ovoga razloga prije pravomoćnog okončanja prijašnjeg postupka činilo

18 Čl. 279. i 281. KZ.

19 Čl. 305. KZ.

20 Obnova spora - izvanredni pravni lijek u upravnosudskom postupku, pristup 23. veljače 2021., https://www.iusinfo.hr/strucni-clanci/CLN20V01D2016B951.

21 Sudac ne može odlučivati niti sudjelovati u sporu:

1. ako je sam stranka, zakonski zastupnik ili opunomoćenik stranke ili ako je sa strankom u odnosu suovlaštenika ili suobveznika,

2. ako mu je stranka ili zakonski zastupnik ili opunomoćenik stranke srodnik po krvi u pravoj liniji do bilo kojeg stupnja, a u pobočnoj do četvrtog stupnja, ili mu je bračni drug, izvanbračni drug ili srodnik po tazbini do drugog stupnja, bez obzira na to je li brak prestao ili nije,

3. ako je skrbnik, posvojitelj ili posvojenik stranke, njezina zakonskog zastupnika ili opunomoćenika,

4. ako je $\mathrm{u}$ istom predmetu sudjelovao u donošenju odluke u upravnom postupku ili prvostupanjskom upravnom sporu te

5. ako postoje druge okolnosti koje dovode u sumnju njegovu nepristranost.

22 Čl. 15. st. 3. ZUS-a.

23 Čl. 15. st. 6. ZUS-a. 
neopravdanim. Kada se ovaj razlog odnosi na suca prvostupanjskog suda, stranka bi trebala učiniti vjerojatnim da je za njega saznala nakon pravomoćnog okončanja postupka, odnosno da postoje opravdane okolnosti koje su ga onemogućile da se pozove na njega najkasnije u žalbi. Ako je riječ o članovima vijeća drugostupanjskog suda, onda bi stranka trebala učiniti vjerojatnim da je za njega saznala nakon što joj je dostavljena drugostupanjska odluka. ${ }^{24}$

\subsubsection{Ako stranka sazna za nove činjenice ili nađe ili stekne mogućnost da upotrijebi nove dokaze na temelju kojih bi spor bio povoljnije riješen za nju da su te činjenice, odnosno dokazi bili izneseni ili upotrijebljeni u prijašnjem sudskom postupku}

Saznanje za nove činjenice ili upotreba novih dokaza jedan je od najčešćih razloga na koji se stranke pozivaju u svom prijedlogu za obnovu spora u nastojanju da stave izvan snage nezakonitu pravomoćnu odluku suda. Ako se nakon pravomoćnosti presude pojave nove činjenice ili novi dokazi, ali samo ako su postojali u ranijem postupku, a stranka za njih nije znala ili ih nije mogla upotrijebiti, a ne i činjenice i dokazi koji su nastali nakon donošenja presude, stranka može podnijeti prijedlog za obnovu upravnog spora. U suprotnom, ako su nove činjenice ili novi dokazi nastali nakon pravomoćne sudske odluke, ovaj razlog za obnovu spora stranka ne može s uspjehom isticati i rezultirat će odbačajem prijedloga za obnovu spora. Bitno je da je riječ o relevantnim činjenicama i dokazima na temelju kojih za stranku može biti donesena povoljnija presuda i da su one, odnosno dokazi bili izneseni u ranijem postupku. Nedostatak takvoga pravnog interesa također će rezultirati odbačajem prijedloga za obnovu spora.

Ponajprije, treba imati na umu da upravnom sporu prethodi upravni postupak, kao i zakonsku odredbu kojom upravni sud nije povezan s činjenicama utvrđenim u upravnom postupku (čl. 33. st. 2. ZUS-a). ${ }^{25}$ Zakonitost osporene odluke upravni sud ispituje prema stanju stvari tijekom vođenja upravnog postupka i donošenja upravnog akta. Sud može i ako ocjeni opravdanim, i sam utvrđivati činjenice i izvoditi dokaze na kojima će utemeljiti svoju odluku. Stoga se može napraviti distinkcija u dopustivosti prijedloga za obnovu upravnog spora u odnosu na nove činjenice i nove dokaze kada upravni sud utemelji svoju odluku na činjeničnom stanju koje je sam utvrdio (spor pune jurisdikcije) i činjeničnom stanju koje je utvrđeno u upravnom postupku, a čiju je ocjenu ispitao prema stanju stvari tijekom donošenja upravnog akta (spor o zakonitosti). Naime, u tom drugom slučaju, ako stranka sazna za nove činjenice i dokaze koji su bili u vrijeme donošenja osporavanoga rješenja, ona uvijek može koristiti izvanredni pravni lijek propisan Zakonom o općem upravnom postupku ${ }^{26}$

24 Jurica Kvartuč, „Procesne pretpostavke za ponavljanje postupka u hrvatskom i njemačkom parničnom procesnom pravu“" Zagrebačka pravna revija 7, br. 2 (2018): 166, https://hrcak.srce. $\mathrm{hr} / 218296$.

25 Sud uzima u obzir činjenice utvrđene u postupku donošenja osporene odluke, kojima nije vezan, i činjenice koje je sam utvrdio.

26 Zakon o općem upravnom postupku, Narodne novine, br. 47/09. 
(obnova upravnog postupka). ${ }^{27}$ Naime, ako sud nije radi utvrđivanja činjeničnog stanja provodio dokaze ne može se niti ostvariti zakonska osnova za obnovu spora iz odredbe čl. 76. st. 1. t. 6. ZUS-a.

Upravni sud u Zagrebu je, primjerice u odluci UsI-1022/19-2 od 29. ožujka 2019. naveo: ...Također nisu ispunjeni uvjeti za obnovu spora iz čl. 76. st. 1. t. 6. ZUS-a, jer je sud činjenično stanje utvrdio uvidom u spis i to na istovjetan način kao u provedenom upravnom postupku, a koje činjenice su se odnosile isključivo na postojanje procesnih pretpostavki za obnovu upravnog postupka. Kako sud nije radi utvrđivanja činjenica provodio dokaze, nije se niti mogla ostvariti zakonska osnova za obnovu spora iz čl. 76. st. 1. t. 6. ZUS-a.

Upravni sud u Rijeci je u odluci UsI-1248/20-2 od 22. listopada 2020. naveo: Međutim, nove činjenice ili novi dokazi u smislu čl. 76. st. 1. tč. 6. ZUS-a jesu one činjenice/dokazi koji su postojali u vrijeme vođenja upravnog spora u kojem je donesena presuda u odnosu na koju se obnova predlaže, ali stranka tada za njih nije znala ili ih nije mogla upotrijebiti (pa su utoliko nove), a ne činjenice/dokazi koji su nastali nakon donošenja presude (iznimno, ukoliko je zbog prirode stvari sud $u$ tijeku spora odluku o zakonitosti upravnog akta temeljio i na činjenicama nastalim nakon upravnog postupka), odnosno nakon okončanja upravnog postupka (budući da u načelu sud zakonitost osporenog upravnog akta ocjenjuje prema stanju stvari $u$ vrijeme donošenja upravnog akta, tj. u vrijeme vođenja upravnog postupka). $U$ konkretnom slučaju, citiranom presudom ovoga suda (na koju se odnosi prijedlog za obnovu), potvrđena je zakonitost inspekcijskog rješenja tuženika KLASA: UP/I342-24/19-03/85, URBROJ: 530-04-5-8-19-9 od 21. svibnja 2019., kojim je tužitelju naloženo na ukloni nedostatke na dijelu operativne luke Krk, koji predstavljaju opasnost za druga plovila i sigurnost plovidbe, pri čemu je sud citiranu presudu utemeljio na činjeničnom stanju u vrijeme vođenja postupka. Slijedom navedenog, činjenice i dokazi na koje se tužitelj poziva (citirana Maritimna studija iz prosinca 2019., rješenje tuženika o prihvaćanju iste od 19. prosinca 2019. te zapisnik o inspekcijskom nadzoru od 25. veljače 2020.) ne predstavljaju nove činjenice i dokaze u smislu čl. 76 st. 1. tč. 6. ZUS-a, budući da nije riječ o činjenicama/dokazima koji su postojali u vrijeme vođenja upravnog postupka, a tužitelj za iste nije znao/nije ih mogao upotrijebiti, već o činjenicama i dokazima koji su nastali nakon okončanja upravnog postupka i upravnog spora.

Visoki upravni sud u odluci Usž-2550/16-2 od 6. listopada 2016., naveo je: Međutim, imajući na umu da se radi o podnesenom zahtjevu za stjecanje prava na obiteljsku invalidninu u smislu čl. 35. Zakona o izmjenama i dopuni Zakona o pravima hrvatskih branitelja iz Domovinskog rata $i$ članova njihovih obitelji ("Narodne novine" 140/12. - dalje: ZID ZOPHBDR-a) te da žaliteljica ukazuje da je u činjenično istoj situaciji (druge tužiteljice) priznato navedeno pravo, što proizlazi iz presude Visokog upravnog suda RH poslovni broj Usž-1491/15-2 od 24. rujna 2015., ovaj Sud je mišljenja da nema zakonske zapreke da se žaliteljica ponovnim zahtjevom obrati tuženiku kako bi se u novom upravnom postupku ponovno odlučilo o ovoj pravnoj stvari.

27 Čl. 123. Zakona o općem upravnom postupku. 
Visoki upravni sud u odluci UsII-134/16 od 11. siječnja 2017. naveo je: Iz spisa predmeta ovoga Suda, posl. broj: UsII-124/15 vidljivo je da je u upravnom sporu čiju obnovu tužitelj traži, predmet ocjene zakonitosti bilo rješenje tuženika kojim je odbačen prijedlog tužitelja za obnovu upravnog postupka dovršenog rješenjem tuženika, klasa: UP/II-008-04/13-01/323, ubroj: 401-01/04-14-05 od 17. veljače 2014. godine. Naime, sud je ocijenio zakonitim rješenje tuženika o odbačaju prijedloga za obnovu postupka zaključivši da ne postoje pretpostavke za obnovu upravnog postupka temeljem razloga koje je tužitelj naveo u prijedlogu, a koji su se odnosili na nenadležnost drugostupanjskog tijela, nepropisno izdavanje potvrde Katoličkog bogoslovnog fakulteta Sveučilišta u Splitu, te na razloge koji dovode u sumnju nepristranost osobe koja je vodila drugostupanjski postupak i donijela rješenje. Stoga je presudom broj: UsII-124/15-2 od 20. kolovoza 2015. Sud odbio tužbeni zahtjev za poništenje rješenja tuženika. Tužitelj traži obnovu spora te u prijedlogu za obnovu navodi da očitovanje doc. dr. sc. Alojzija Čondića ne sadrži podatke koji bi se trebali štititi, što dokazuje izvatkom iz telefonskog imenika koji sadrži osobne podatke navedene u očitovanju. Budući da se radi o novoj okolnosti odnosno činjenici koja se odnosi na meritorno rješavanje zahtjeva o pravu na pristup informacijama što nije bilo predmet raspravljanja u ranije okončanom sporu (predmet kojeg je bila obnova upravnog postupka), ista ne može biti valjani razlog za obnovu upravnog spora već eventualno može biti razlog za obnovu upravnog postupka pod uvjetima propisanim u glavi III. Zakona o općem upravnom postupku (Narodne novine, 47/09.). U odnosu na ostale razloge za obnovu spora koje navodi, a koji se odnose na sumnju u pristranost službene osobe i nenadležnost tijela drugog stupnja tužitelj ne iznosi ništa što nije bilo već poznato i ocijenjeno u ranijem pravomoćno okončanom postupku.

\subsubsection{Ako zainteresiranoj osobi nije dana mogućnost sudjelovanja u upravnom sporu}

Pored tužitelja ${ }^{28}$ i tuženika, ${ }^{29}$ pravni položaj stranke u upravnom sporu ima i zainteresirana osoba koja može istupati na strani tužitelja ili na strani tuženika. ${ }^{30}$ No, položaj zainteresirane osobe uz tužitelja i tuženika u sporu može imati i javnopravno

28 Čl. 17. ZUS-a propisano je da je tužitelj fizička ili pravna osoba koja smatra da su joj prava i pravni interesi povrijeđeni pojedinačnom odlukom, postupanjem javnopravnog tijela, odnosno propuštanjem donošenja pojedinačne odluke ili postupanja javnopravnog tijela u zakonom propisanom roku ili sklapanjem, raskidom ili izvršavanjem upravnog ugovora (st. 1.). Tužitelj može biti osoba koja nema pravne osobnosti ili skupina osoba ako su pojedinačnom odlukom ili postupanjem javnopravnog tijela povrijeđena njihova prava i pravni interesi (st. 2.). Tužitelj može biti javnopravno tijelo koje je sudjelovalo ili je trebalo sudjelovati u donošenju odluke, postupanju ili sklapanju upravnog ugovora (st. 3.).Tužitelj može biti i državno tijelo ovlašteno zakonom (st. 4.).

29 Čl. 18. ZUS-a propisano je da je tuženik javnopravno tijelo koje je donijelo ili propustilo donijeti pojedinačnu odluku, postupilo ili propustilo postupiti, odnosno koje je stranka upravnog ugovora.

30 Čl. 19. st. 1. ZUS-a propisano je da je zainteresirana osoba svaka osoba kojoj bi poništavanje, izmjena ili donošenje pojedinačne odluke, postupanje ili propuštanje postupanja javnopravnog tijela, odnosno sklapanje, raskid ili izvršavanje upravnog ugovora povrijedilo njezino pravo ili pravni interes. 
tijelo koje smatra da sudska odluka može imati učinak na prava i pravne interese koje ono štiti na temelju zakona. ${ }^{31}$ Uskrata sudjelovanja nekoj od osoba koja je u spor trebala biti uključena u svojstvu zainteresirane osobe u višestranačkim stvarima otvara mogućnost toj stranci podnošenje prijedloga za obnovu spora. Zainteresirana osoba pred upravnim sudom najčešće se pojavljuje u imovinsko-pravnoj oblasti, a gdje prema upravno-sudskoj praksi i ima najviše prihvaćenih prijedloga za obnovu upravnog spora jer osobi koja je trebala sudjelovati kao stranaka u postupku nije dana takva mogućnost, odnosno sud je propustio takvu osobu uključiti u upravni spor kako bi mogla zaštititi svoja prava i interese.

Upravni sud u Zagrebu je, primjerice, u odluci UsI-3559/17-11 od 30. listopada 2019. u kojoj je dopustio obnovu spora te stavio izvan snage svoju raniju presudu i poništio osporeno i prvostupanjsko rješenje naveo: Zainteresirana osoba podnijela je prijedlog za obnovu navedenog spora navodeći kako istome, iako je zainteresirana osoba, nije bila dana mogućnost sudjelovanja u sporu slijedom čega podnosi prijedlog sukladno čl. 76. st. 1. t. 7. Zakona o upravnim sporovima (Narodne novine broj 20/10, 143/12, 152/14 i 29/17- dalje: ZUS). Prijedlog za obnovu upravnog spora je osnovan. Naime, prema dugogodišnjoj upravnoj sudskoj praksi, jedinica lokalne samouprave ima pravni položaj zainteresirane osobe u sporovima određivanja $i$ naplate komunalnog doprinosa, jer se radi o sporu u kojem se odlučuje o njenom samoupravnom pravu na plaćanje komunalnog doprinosa.

\subsection{Rokovi za podnošenje prijedloga za obnovu spora}

Odredbom članka 76. stavka 2. ZUS-a propisani su rokovi za podnošenje prijedloga za obnovu upravnog spora. ${ }^{32}$ Možemo ih podijeliti na subjektivni i objektivni rok. Subjektivni rok je rok čiji početak ovisi o saznanju stranke za razlog obnove i iznosi 30 dana, a počinje teći isto za sve razloge koji su propisani kao razlozi obnove upravnog spora. S druge strane, objektivni se rok računa od nastupa pravomoćnosti presude. Nakon isteka objektivnog roka od jedne godine od pravomoćnosti presude ne može se više predlagati obnova spora u situacijama koje se tiču povrede pravila o izuzeću suca, saznanja za nove činjenice ili nove dokaze i ne davanja mogućnosti zainteresiranoj osobi da sudjeluje u upravnom sporu. Ova situacija s objektivnim rokom može se tumačiti dvojako i to tako da za sve situacije za koje nije propisan objektivni rok stranka je povezana isključivo subjektivnim rokom. Ili suprotno da u ostalim slučajevima stranka može i nakon proteka jedne godine od pravomoćnosti presude predložiti obnovu za razloge koje nisu povezani s objektivnim rokom. Neki autori tumače navedene rokove tako da za sve ostale slučajeve za koje objektivni rok nije propisan stranka je isključivo povezana sa subjektivnim rokom. ${ }^{33}$ Zakonodavac

31 Čl. 19. st. 2. ZUS-a propisano je da je zainteresirana osoba i javnopravno tijelo koje smatra da sudska odluka može imati učinak na prava i pravne interese koje to javnopravno tijelo štiti na temelju zakona.

32 Prijedlog za obnovu spora podnosi se sudu koji je donio presudu najkasnije u roku od 30 dana od dana kad je stranka saznala za razlog obnove. Nakon proteka jedne godine od pravomoćnosti presude obnova se ne može predložiti iz razloga propisanog st. 1. t. 5., 6. i 7. ovoga članka.

33 Dario Đerđa i Marko Šikić, Komentar Zakona o upravnim sporovima (Zagreb: Novi Informator, 
se kod toga izvanrednog pravnog lijeka opredijelio za dvije vrste rokova te ih je neprecizno uredio, odnosno nije osigurao njihovu jasnoću i određenost, a što može rezultirati neujednačenom praksom upravnih sudova.

\subsection{Postupak i pretpostavke za obnovu spora}

Predmet je obnove postupak koji je pravomoćno okončan presudom suda. To znači da protiv upravnog spora koji je okončan rješenjem (obustava upravnog spora, odbačaj tužbe) nema mogućnosti obnove. ${ }^{34}$ Vezano za presude kojima se okončava upravni spor, to mogu biti prvostupanjske kao i drugostupanjske presude, odnosno presude Visokog upravnog suda. Prijedlog za obnovu spora je vrsta podneska kojim stranke predlažu da se ranija presuda suda stavi izvan snage i da se donese nova odluka te kao i svaki drugi podnesak mora obuhvaćati elemente propisane ZUS-om. ${ }^{35}$ S obzirom na to da je prijedlog za obnovu spora vrsta pisanog podneska, na njegovu urednost i način predaje primjenjuje se odredba članka 49. ZUS-a. ${ }^{36}$

O prijedlogu za obnovu odlučuje isti sudac prvostupanjskog suda, odnosno isto vijeće drugostupanjskog suda, osim ako se obnova predlaže zbog razloga propisanog odredbom čl. 76. st. 1. t. 5. ZUS-a. U tom slučaju o obnovi ne može odlučivati isti sudac, jer se meritum predmeta obnove sastoji u utvrđivanju razloga za izuzeće toga suca u sporu koji je okončan. ${ }^{37}$

2012.), 170 .

34 Upravni sud u Rijeci, UsI-853/17-8 od 24. siječnja 2018., Visoki upravni sud Republike Hrvatske, Usž-100/20-2 od 13. svibnja 2020.

35 Čl. 76. st. 3. ZUS-a propisano je da se u prijedlogu mora navesti:

1. oznaka presude donesene u sporu kojeg se obnova traži,

2. zakonska osnova obnove i dokazi koji je čine vjerojatnom,

3. dokazi da je prijedlog podnesen u zakonskom roku,

4. ostali podatci propisani čl. 49. st. 2. ovoga Zakona te

36 1. Podnesci se dostavljaju u pisanom ili elektroničkom obliku.

2. Podnesak mora biti razumljiv te obuhvaćati sve potrebno da bi se u svezi s njim moglo postupiti, osobito oznaku suda, osobno ime, odnosno naziv i adresu stranke i osoba ovlaštenih za zastupanje, predmet spora, sadržaj izjave te potpis. Podnesak dostavljen elektronički treba biti ovjeren elektroničkim potpisom sukladno sa zakonom.

3. Ako podnesak nije razumljiv ili ne obuhvaća sve potrebno da bi se po njemu moglo postupiti, sud će podnositelju naložiti da podnesak ispravi, odnosno dopuni i za to mu odrediti primjereni rok. Ako se nedostatci u roku ne otklone, a po podnesku se ne može postupiti, smatrat će se da podnesak nije niti podnesen.

4. Podnesak dostavljen elektroničkim putem smatra se predanim sudu u trenutku kad je zabilježen na poslužitelju za slanje takvih poruka. Sud će bez odgode elektroničkim putem pošiljatelju potvrditi primitak podneska.

5. Ako sud iz tehničkih razloga ne može pročitati podnesak u elektroničkom obliku, o tome će obavijestiti pošiljatelja i pozvati ga da u roku koji je za to određen pošalje podnesak u ispravnom elektroničkom obliku ili da ga dostavi na drugi način. Ako pošiljatelj to ne učini $u$ roku, smatrat će se da podnesak nije niti podnesen.

6. Izjava koja se daje podneskom može se sudu dati i usmeno na zapisnik.

37 Obnova spora - izvanredni pravni lijek u upravnosudskom postupku, pristup 23. veljače 2021., https://www.iusinfo.hr/strucni-clanci/CLN20V01D2016B951. 
Odredbom čl. 77. st. 1. ZUS-a, ${ }^{38}$ propisani su razlozi zbog kojih sud odbacuje prijedlog za obnovu spora, odnosno riječ je o formalnim pretpostavkama, koje ako nisu ispunjene, rezultirat će nedopuštenošću prijedloga i njegovim odbačajem. U suprotnom, ako sud ne odbaci prijedlog za obnovu spora, dostavlja ga drugim strankama kako bi dostavile odgovor na prijedlog u roku od 15 dana. ${ }^{39}$ Ako sud dopusti obnovu upravnog spora prijašnja će se odluka staviti izvan snage u cijelosti ili djelomično. Prijašnje radnje, na koje ne utječu razlozi obnove neće se obnavljati, a presudom kojom se obnova dopušta odlučit će se o predmetu spora. ${ }^{40}$

\subsection{Obnova upravnog spora u sudskoj praksi}

Za potrebe ovog rada zatraženi su podatci od upravnih sudova o broju zaprimljenih prijedloga za obnovu upravnog spora, broju odluka koje su rezultirale odbačajem prijedloga i broju odluka koje su rezultirale dopuštanjem obnove spora i stavljanjem izvan snage pravomoćne presude od 2010. do 2020. Dobiveni podatci tablično su prikazani u nastavku rada.

Upravni sud u Zagrebu:

Tablica 1. Broj zaprimljenih prijedloga po godinama Upravnog suda u Zagrebu

\begin{tabular}{|c|c|}
\hline Godina & Broj zaprimljenih prijedloga \\
\hline 2012 & 1 \\
\hline 2013 & 6 \\
\hline 2014 & 8 \\
\hline 2015 & 28 \\
\hline 2016 & 4 \\
\hline 2017 & 11 \\
\hline 2018 & 14 \\
\hline 2019 & 9 \\
\hline 2020 & 33 \\
\hline
\end{tabular}

Tablica 2. Načini rješavanja predmeta Upravnog suda u Zagrebu

\begin{tabular}{|c|c|}
\hline Način rješavanja & Broj riješenih predmeta \\
\hline Odbačeno & 65 \\
\hline Obustava & 1 \\
\hline Ustup - VUS RH & 31 \\
\hline Odbijeno & 2 \\
\hline Usvojeno & 3 \\
\hline Neriješeno & 12 \\
\hline
\end{tabular}

Iz gore navedenih podataka vidljivo je kako je od 2012. do 2020. Upravni sud u Zagrebu riješio $89,5 \%$ prijedloga, od čega je odbacio $56 \%$, a usvojio samo $2,6 \%$ prijedloga.

38 Sud će odbaciti prijedlog rješenjem ako utvrdi da je prijedlog podnijela neovlaštena osoba ili da je prijedlog nepravodoban ili da stranka nije učinila vjerojatnim postojanje zakonske osnove za obnovu.

39 Čl. 77. st. 2. ZUS-a.

40 Čl. 77. st. 3. ZUS-a. 
Upravni sud u Rijeci:

Tablica 3. Broj zaprimljenih prijedloga po godinama Upravnog suda u Rijeci

\begin{tabular}{|c|c|}
\hline Godina & Broj zaprimljenih prijedloga \\
\hline 2012 & 1 \\
\hline 2013 & 6 \\
\hline 2014 & 8 \\
\hline 2015 & 9 \\
\hline 2016 & 7 \\
\hline 2017 & 5 \\
\hline 2018 & 1 \\
\hline 2019 & 18 \\
\hline 2020 & 11 \\
\hline
\end{tabular}

Tablica 4. Načini rješavanja predmeta Upravnog suda u Rijeci

\begin{tabular}{|c|c|}
\hline Način rješavanja & Broj riješenih predmeta \\
\hline Neriješeno & 3 \\
\hline Ini način & 1 \\
\hline Odbačeno & 54 \\
\hline Obustava & 2 \\
\hline Odbijeno & 2 \\
\hline Usvojeno & 3 \\
\hline Ustupljeno & 1 \\
\hline
\end{tabular}

Iz navedenih je podataka vidljivo kako je u osam godina Upravni sud u Rijeci zaprimio 66 prijedloga za obnovu spora. Riješeno je 95,5\% prijedloga, od čega je odbacio $82 \%$, a usvojio $4,5 \%$ prijedloga.

Upravni sud u Osijeku:

Prema podatcima dobivenim od Upravnog suda u Osijeku, od 2012. do 2020. zaprimljeno je ukupno 46 prijedloga za obnovu upravnog spora, od čega je 45 prijedloga odbačeno, a samo je jedan prijedlog dopušten i stavljena je izvan snage presuda toga suda. To bi značilo da je odbačeno čak $98 \%$ prijedloga, a $2 \%$ usvojeno.

\section{ZAHTJEV ZA IZVANREDNO PREISPITIVANJE ZAKONITOSTI PRAVOMOĆNE ODLUKE}

Zahtjev za izvanredno preispitivanje zakonitosti pravomoćne odluke također je izvanredni pravni lijek koji je uveden u hrvatsko upravno sudovanje novim ZUS-om iz 2010.

Zakonodavac se dva puta umiješao u navedeni pravni lijek tako da je Novelom ZUS-a iz 2012., pojam sudske odluke zamijenio pojmom presuda. Također je dodao odredbu da su sud protiv čije je presude podnesen zahtjev za izvanredno preispitivanje pravomoćne odluke i javnopravno tijelo kao tuženik dužni bez odlaganja dostaviti Vrhovnom sudu na njegov zahtjev sve spise predmeta. Drugom novelom ZUS-a iz 2014. učinjene su izmjene i dopune instituta, i to tako da je podnošenje zahtjeva prošireno osim na pravomoćne presude i na rješenja. S obzirom na sam naziv ovog izvanrednog 
pravnog lijeka i dodane nove odredbe, sud je ovlašten nepravodoban zahtjev ili zahtjev koji je podnijela neovlaštena osoba, odbaciti rješenjem. ${ }^{41} \mathrm{U}$ suprotnom ako sud ne odbaci zahtjev dostavlja ga protivnoj stranci koja može u roku od 30 dana podnijeti odgovor na zahtjev. ${ }^{42}$ Zahtjev rješava Vrhovni sud na nejavnoj sjednici u vijeću koje čini pet sudaca, a pobijanu odluku ispituje samo u granicama zahtjeva. ${ }^{43}$ Nerijetko se događa da stranke inicijativu za podnošenje zahtjeva dostavljaju upravnim sudovima, a pritom sudovi takve zahtjeve bez odgode prosljeđuju DORH-u.

Važna karakteristika toga pravnog lijeka je što ga može inicirati stranka, a samo ga može podnijeti DORH, ili na inicijativu stranke, ili po službenoj dužnosti. Dakle, konačno korištenje zahtjeva ovisi isključivo o prosudbi DORH-a, o postojanju ili nepostojanju razloga za podnošenje zahtjeva Vrhovnom sudu. Takav je zakonodavčev pristup djelomično opravdan i logičan. Željela se izbjeći opasnost da nezadovoljne stranke iz upravnog spora pretjerano opterećuju Vrhovni sud svojim izravnim zahtjevima za preispitivanje sudskih odluka. Vidljivo je kako je takvim zakonodavčevim pristupom naglasak stavljen na osiguravanje jedinstvene primjene prava i ravnopravnosti građana od strane Vrhovnoga suda, dok je uloga zahtjeva kao pravnog sredstva koji je na raspolaganju i građanima, kao i drugim strankama u upravnom sporu, ostala u drugom planu. ${ }^{44}$

Primjerice Vrhovni sud je u rješenju U-zpz 14/2013-2 od 1. listopada 2014., naveo: ....dakle, kako predlagatelj nije osoba koja bi, u konkretnom slučaju, bila legitimirana podnijeti zahtjev za izvanredno preispitivanje zakonitosti predmetne presude, jer je na to legitimirano samo Državno odvjetništvo Republike Hrvatske, proizlazi da je predmetni zahtjev izjavila neovlaštena osoba, pa je temeljem odredbe čl. 78. st. 2. i 3. ZUS-a odlučeno kao u izreci.

ZUS nije propisao zbog kojih se razloga može podnijeti ovaj izvanredni pravni lijek kao što je to uređeno kod obnove upravnog spora, ali je sasvim jasno da se podnosi protiv odluka upravnih sudova (presuda i rješenja) ${ }^{45}$ i Visokog upravnog suda za koje se smatra da je njima povrijeđen zakon, odnosno odredbe materijalnog i postupovnog prava. Povrede zakona katkad se u upravnom sporu mogu otkloniti tek izvanrednim pravnim lijekom, a to je u situacijama kada protiv presuda i rješenja žalba nije dopuštena. ${ }^{46}$ Povrede zakona zbog kojih se podnosi zahtjev mogu se odnositi na povrede odredbi ZUS-a i odredbi nekoga drugog materijalnog Zakona.

41 Čl. 78. st. 4. ZUS-a.

42 Čl. 78. st. 5. ZUS-a.

43 Čl. 78. st. 3. i 6. ZUS-a.

44 Marko Šikić, „Primjena zahtjeva za izvanredno preispitivanje zakonitosti pravomoćne presude“, Zbornik radova Pravnog fakulteta u Splitu 54, br. 1 (2017): 181, https://doi.org/10.31141/ zrpfs.2017.54.123.179.

45 Glava V. ZUS-a pod naslovom „Sudske odluke“.

46 Čl. 66. st. 1.i 2. ZUS-a propisano je da žalba nije dopuštena protiv presude kojom je pojedinačna odluka javnopravnog tijela poništena ili oglašena ništavom i predmet prvi put vraćen na ponovni postupak, kao ni protiv presude kojom je sud naložio donošenje pojedinačne odluke koja nije donesena u propisanom roku. Protiv dijela presude iz čl. 89. st. 4. ovog Zakona u koji je uključen sadržaj sudske nagodbe žalba nije dopuštena. Čl. 67. st. 1. ZUS-a protiv rješenja upravnog suda žalba može se podnijeti samo ako je to propisano ovim Zakonom. Žalba nije dopuštena protiv rješenja Visokog upravnog suda. 
Mišljenje autorice je da kod podnošenja zahtjeva DORH nije vezan činjenicom je li ta povreda utjecala ili nije na donošenje pravomoćne odluke, nego uvijek kada smatra da je Zakon povrijeđen, ovlašten je podnijeti zahtjev. Također, smatra da se zahtjev ne može podnijeti zbog toga što je činjenično stanje pogrešno ili nepotpuno utvrđeno, niti se u zahtjevu mogu iznositi nove činjenice jer u protivnom takav pravni lijek gubi smisao i izjednačilo bi ga se sa žalbom čime bi se nepotrebno otvorio još jedan stupanj osporavanja odluka upravnih sudova, a što nije bila namjera zakonodavca kod propisivanja takva pravnog lijeka, posebice jer je riječ o izvanrednom pravnom lijeku.

Vrhovni je sud, primjerice, u presudi U-zpz 1/17-5 od 12. rujna 2017., naveo: ... kada su činjenice odlučne za odluku u upravnom sporu, sporne, onda se nameće zaključak kako u okolnostima konkretnog slučaja nisu bile ispunjene pretpostavke propisane odredbom čl. 36. t. 4. ZUS-a koje bi dopustile rješavanje ovog upravnog spora bez održavanja rasprave.

U rješenju U-zpz 12/2017-7 od 8. prosinca 2020., Vrhovni je sud usvojio zahtjev za izvanredno preispitivanje presude te ukinuo rješenje Upravnog suda u Splitu broj Usljn-36/16-9 od 25. listopada 2016. Njime je odgođeno izvršenje odluka tuženika Lučke uprave Split, Upravnog vijeća od 18. srpnja 2016., te je odgođena provedba postupka dodjele koncesije, kao i provedba svakoga drugog postupka dodjele koncesije na pomorskom dobru za obavljanje lučkih djelatnosti na lučkom području trajektne luke Split od strane Lučke uprave Split do pravomoćnog dovršenja toga upravnog spora, a u predmetu prvenstvene koncesije na pomorskom dobru. Vrhovni sud je u navedenoj odluci između ostaloga naveo: ...S obzirom da je u odlučivanju o prijedlogu za donošenje privremene mjere ( $t$. 2. i 3. izreke rješenja) počinjena bitna povreda odredbi pravila sudskog postupka iz čl. 66. st. 1. t. 1. ZUS-a, jer upravni sud u tijeku spora nije primijenio odredbe čl. 6. i čl. 67. st. 1. ZUS-a, a to je utjecalo na donošenje zakonite i pravilne odluke to je u tom dijelu bilo nužno prihvatiti zahtjev tuženice, ukinuti pobijano rješenje u tom dijelu i predmet vratiti na ponovno rješavanje istom sudu, pozivom na čl. 78. st. 7. ZUS-a.... Što se tiče odgodnog učinka odluke Lučke uprave Split od 18. travnja 2016., ističe se da je taj dio zahtjeva nužno prosuđivati kroz odredbu čl. 26. st. 2. ZUS-a. Ta odredba pretpostavlja postojanje pojedinačne odluke ili upravnog ugovora čim bi se izvršavanjem tužitelju nanijela šteta koja bi se teško mogla popraviti, pretpostavlja da zakonom nije propisano da žalba ne odgađa izvršenje pojedinačne odluke, te da takva odgoda nije protivna javnom interesu. U konkretnom slučaju radi se o pravomoćnoj odluci upravnog tijela kojom je odbijen zahtjev tužiteljice za produženje prvenstvene koncesije protiv koje je podnesena tužba upravnom sudu s prijedlogom za odgodnim učinkom tužbe i određivanjem privremene mjere. Protiv donesene odluke nije dopuštena žalba, pa je bilo nužno ispitati bi li se izvršavanjem upravnog rješenja kojim je pravomoćno odbijen zahtjev tužiteljice za produženje prvenstvene koncesije tužiteljici nanijela šteta koja bi se teško mogla popraviti i je li eventualna odgoda izvršenja te odluke protivna javnom interesu... Stoga, za sada, nije prihvatljivo navedeno shvaćanje upravnog suda prema kojem odgoda ne bi bila protivna javnom interesu, jer javni interes svakako predstavlja zakonito obavljanje djelatnosti.

U presudi U-zpz 23/18-2 od 5. prosinca 2018., Vrhovni sud je potvrdio stajalište 
Visokog upravnog suda: o zahtjevu tužitelja za izdavanje lokacijske dozvole treba odlučiti primjenom Odluke o donošenju prostornog plana koji je bio na snazi u vrijeme donošenja prvostupanjskog rješenja“.

U presudi broj: U-zpz 17/16-8 od 11. travnja 2017., Vrhovni sud je ukinuo presudu Visokog upravnog suda Usž-1788/15-2 od 22. listopada 2015 i pritom je naveo: Dakle, donoseći pobijanu drugostupanjsku presudu drugostupanjski sud povrijedio je zakon i to odredbu čl. 27. st. 5. Zakona o porezu na dohodak i odredbu čl. 7. Općeg poreznog zakona.

Ako Vrhovni sud usvoji zahtjev, osporenu presudu može ukinuti i vratiti predmet na ponovno rješavanje ili preinačiti presudu ${ }^{47}$ Neki autori smatraju da je upitna ispravnost navedenoga zakonskog rješenja da Vrhovni sud preinači presudu ako je Vrhovni sud preispitivao prvostupanjsku odluku upravnog suda. Naime, smatraju da preinačujući presudu upravnog suda, Vrhovni sud preuzima na sebe ovlasti Visokog upravnog suda, a to u budućoj praksi može izazvati određene teškoće. ${ }^{48}$ Međutim, u suprotnim situacijama kada upravni sud usvoji tužbeni zahtjev i vrati predmet tijelu prvi put na ponovno odlučivanje, pa nije dopušteno izjavljivanje žalbe Visokom upravnom sudu (čl. 66. ZUS-a), preinačavanje presude upravnog suda od strane Vrhovnog suda je upravo postupanje toga suda u skladu s ovlastima koje on ima. Bitno je naglasiti da je Vrhovni sud na sjednici Građanskog odjela, broj Su-IV-270/17 od 29. srpnja 2017., zauzeo pravno shvaćanje da je protiv odluke upravnog suda kojom su poništena rješenja upravnih tijela i predmet vraćen ponovni postupak, dopušten zahtjev za izvanredno preispitivanje zakonitosti pravomoćne presude i rješenja.

Primjerice Vrhovni sud je u presudi U-zpz 25/17-6 od 13. ožujka 2018., presudio: Zahtjev se usvaja, preinačava se presuda Upravnog suda u Rijeci broj UsI-897/14-10 od 28. prosinca 2016. i sudi: Odbija se kao neosnovan tužbeni zahtjev za poništenje rješenja Ministarstva graditeljstva i prostornog uređenja Republike Hrvatske, klasa: UP/II-361-05/14-26/291, ur. broj: 531-05-2-2-14-2 od 22. travnja 2013.

Vrhovni sud će uvijek odbiti zahtjev ako utvrdi da nema povrede na kojima se zahtjev temelji, odnosno one na koje se DORH u zahtjevu poziva, bez obzira na to ako i uoči neke druge povrede koje nisu navedene u zahtjevu (u granicama zahtjeva čl. 78. st. 6. ZUS-a). Uz to što je Sud vezan, ne samo granicama ispitivanja osporene presude određenih čl. 78. st. 6 . ZUS-a, vezan je i predmetnim tužbenim zahtjevom te vrstom spora.

Vrhovni je sud, primjerice, u presudi U-zpz 2/2019-10 od 8. siječnja 2020., naveo: Konačno za ukazati je da ovaj sud nije ispitivao da li bi tužitelj bio u obvezi naknaditi korist ostvarenu korištenjem predmetnog dobra (sve u smislu odredaba zakona o vlasništtvu i drugim stvarnim pravima - „Narodne novine “ broj 91/96, 68/98 i 137/99 u smislu odredaba Zakona o obveznim odnosima - „Narodne novine “ broj 35/05, 47/08). Ovo stoga što je u ovom postupku ovaj sud vezan ne samo granicama ispitivanja pobijane presude određenih čl. 78. st. 6. ZUS-a već iz razloga što je vezan predmetnim tužbenim zahtjevom te vrstom spora.

Bitno je i napomenuti da zakonodavac kod navedenoga izvanrednog pravnog

47 Čl. 78. st. 8. ZUS-a.

48 Đerđa i Šikić, Komentar Zakona o upravnim sporovima, 293. 
lijeka nije uredio situaciju kada DORH odustane od podnesenog zahtjeva ili ga se odrekne. Stoga bi analogno navedenom, takav zahtjev trebalo odbaciti rješenjem.

\section{ZAKLJUČAK}

U radu su razmotrena dva izvanredna pravna lijeka, kojima se osigurava uklanjanje nezakonitosti u upravnom sporu, samo pod točno propisanim uvjetima. Prikazana je sudska praksa sudova u formuliranju odluka u povodu navedenih izvanrednih pravnih lijekova. Može se uočiti kako je mali broj zahtjeva stranaka za ponovnim preispitivanjem odluka upravnih sudova, odnosno za intervencijom u pravomoćne sudske odluke, a u povodu obnove upravnog spora. S obzirom na to da je obnova upravnog spora dopuštena samo u odnosu na presude, ali ne i u odnosu na rješenja kojima se u velikom broju odluka i okonča upravni spor, ukazuje se na propust zakonodavca koji se može eventualno ispraviti u nekim daljnjim noveliranjima ZUS-a, tako da se ovaj izvanredni pravni lijek dopusti i u odnosu na rješenja kojima se okončava upravni spor. Nejasno su uređeni i rokovi za obnovu upravnog spora, odnosno zakonodavac nije osigurao njihovu jasnoću i određenost, a što može rezultirati neujednačenom praksom upravnih sudova. Uočava se kako je u odnosu na broj podnesenih prijedloga za obnovu spora veći dio podnesenih prijedloga za obnovu spora odmah odbačen zbog neispunjavanja procesnih pretpostavki, te je također i mali broj pozitivnih odluka o prijedlogu. Navedeno može ukazivati na činjenicu da su odluke upravnih sudova pravno i procesno utemeljene ili da se stranke zbog složene procesne koncepcije rijetko upuštaju u ponovni upravni spor. U odnosu na drugi izvanredni pravni lijek, zahtjev za izvanredno preispitivanje zakonitosti pravomoćne odluke, koji se za razliku od obnove upravnog spora može podnijeti i protiv rješenja, ali je u diskrecijskoj ovlasti DORH-a jer podnošenje toga pravnog lijeka isključivo ovisi o prosudbi DORH-a, o postojanju ili ne postojanju razloga za njegovo podnošenje Vrhovnom sudu. Kada će DORH iskoristiti ovu mogućnost ostavljeno mu je na dispoziciju. To bi značilo da nije vezan činjenicom je povreda utjecala ili nije na donošenje pravomoćne odluke, ali DORH ima ovlast podnijeti zahtjev uvijek kada smatra da je zakon povrijeđen, iako nije na to obvezan. Podnesak stranke upućen DORH-u samo je inicijativa za pokretanje postupka koja može i ne mora biti prihvaćena. Međutim, autorica bi se odlučila za takav pristup zakonodavca pri reguliranju navedenog izvanrednog pravnog lijeka. Razlog tomu je, kao što je i navedeno u radu, davanje mogućnosti strankama da podnose izravno zahtjeve Vrhovnom sudu znatno bi opteretilo taj sud s nezadovoljnim strankama i stavilo bi ga se u ulogu suda drugog stupnja, što nije bila namjera zakonodavca pri propisivanju toga izvanrednog pravnog lijeka.

\section{Knjige i članci:}

\section{LITERATURA}

1. Đerđa, Dario i Marko Šikić. Komentar Zakona o upravnim sporovima. Zagreb: Novi Informator, 2012.

2. Kaleb, Zorislav. Djelovanje kaznene presude na parnični postupak. Zagreb: Vizura, 2008. 
3. Kontrec, Damir i Vitomir Boić. Konvencija za zaštitu ljudskih prava i temeljnih sloboda $i$ praksa ESLJP - Građanskopravni aspekt: Priručnik za voditelje/ice. Zagreb: Pravosudna akademija, 2017.

4. Kvartuč, Jurica. „Procesne pretpostavke za ponavljanje postupka u hrvatskom i njemačkom parničnom procesnom pravu“. Zagrebačka pravna revija 7, br. 2 (2018): 57 99, https://hrcak.srce.hr/218296

5. Obnova spora - izvanredni pravni lijek u upravnosudskom postupku. Pristup 23. veljače 2021., https://www.iusinfo.hr/strucni-clanci/CLN20V01D2016B951

6. Šikić, Marko. „Primjena zahtjeva za izvanredno preispitivanje zakonitosti pravomoćne presude“. Zbornik radova Pravnog fakulteta u Splitu 54, br. 1 (2017): 179-201, https:// doi.org/10.31141/zrpfs.2017.54.123.179

7. Triva, Siniša i Mihajlo Dika. Građansko parnično procesno pravo. Zagreb: Narodne novine, 2004.

Pravni propisi:

1. Kazneni zakon, Narodne novine, br. 125/11., 144/12., 56/15., 61/15., 101/17., 118/18., $126 / 19$.

2. Konvencija za zaštitu ljudskih prava i temeljnih sloboda, Narodne novine, Međunarodni ugovori, br. 18/97., 6/99., 14/02., 13/03., 9/05., 1/06., 2/10.

3. Zakon o općem upravnom postupku, Narodne novine, br. 47/09.

4. Zakon o upravnim sporovima, Narodne novine, br. 20/10., 143/12., 152/14., 94/16., 29/17.

5. Zakon o upravnim sporovima, Narodne novine, br. 53/91., 9/92. i 77/92.

Sudska praksa:

1. UsI-1022/19-2 od 29. ožujka 2019.

2. UsI-1248/20-2 od 22. listopada 2020.

3. UsI-1540/13-11 od 30. svibnja 2016.

4. UsI-3559/17-11 od 30. listopada 2019.

5. UsI-4965/13-5 od 26. ožujka 2015.

6. U-III-3304/2011 od 23. siječnja 2013.

7. UsI-853/17-8 od 24. siječnja 2018.

8. UsI-910/19-31 od 22. ožujka 2019.

9. UsII-134/16 od 11. siječnja 2017.

10. Usž-100/20-2 od 13. svibnja 2020.

11. Usž-100/20-2 od 13. svibnja 2020.

12. Usž-2550/16-2 od 6. listopada 2016.

13. U-zpz 1/17-5 od 12. rujna 2017.

14. U-zpz 12/2017-7 od 8. prosinca 2020.

15. U-zpz 14/2013-2 od 1. listopada 2014.

16. U-zpz 17/16-8 od 11. travnja 2017.

17. U-zpz 2/2019-10 od 8. siječnja 2020.

18. U-zpz 23/18-2 od 5. prosinca 2018.

19. U-zpz 25/17-6 od 13. ožujka 2018. 


\section{Meri Dominis Herman*}

\section{Summary \\ EXTRAORDINARY LEGAL REMEDIES IN THE ADMINISTRATIVE DISPUTE}

This paper analyzes two extraordinary legal remedies prescribed by the Law of Administrative Disputes; Reopening of an administrative dispute and Request for extraordinary review of the legality of a final judgment. The specifics of each of them are elaborated with a presentation of the jurisprudence of the administrative courts, the High Administrative Court of the Republic of Croatia and the Supreme Court of the Republic of Croatia. The author concludes that there is an omission of the legislator when he opted only for the reopening of a dispute terminated by a verdict, and not by a decision, which can be corrected in some further amendments to the Law of Administrative Disputes. Also, the vagueness are pointed out when regulating the deadlines for the reopening of an administrative dispute and it is noticed that a large number of submitted proposals for reopening of an administrative dispute were immediately rejected, and there is a very small number of positive decisions on the proposals. The author concludes that this indicates the fact that the decisions of administrative courts are legally and procedurally grounded, or that the parties due to the complex procedural concept rarely engage in a new administrative dispute. Furthermore, the author opts for the legislator's approach in regulating the request for extraordinary review of the legality of a final judgment, because giving the parties the opportunity to submit requests directly to the Supreme Court would significantly burden that court and put it in a role of a court of second instance, which was not the intention of the legislator when prescribing this extraordinary legal remedy.

Keywords: extraordinary legal remedies; reopening of an administrative dispute; request for extraordinary review of the legality of a final judgment; Law of administrative disputes.

* Meri Dominis Herman, dipl. iur., Judge of the Administrative Court in Zagreb; meri. dominisherman@uszg.pravosudje.hr. ORCID: https://orcid.org/ 0000-0002-6875-6088. 
